\title{
Educational and Psychological Impacts of Corona-phobia and Movement Control Order
}

\author{
Sa'adu Isa Bashar, Ramatu Muhammad Maiwada, Abdulmumini Inda
}

\begin{abstract}
Covid19's pandemic outbreak has dwarfed the global community to its knees so that the world was enveloped by panic, uncertainty and confusion. The quest for measures to control the plague has remained a challenging priority for each nation. Some of the world's most popular measures include restricting the movement of peoples, social distancing and isolation. Such tactics have created a great deal of mayhem, crises, and ultimately influence all social life interests including schooling, economy, religion and others. This study seeks to examine the educational and psychological impacts of Corona-phobia and the Movement Control Order (MCO) rule on Nigerian graduate students in Universiti Teknologi Malaysia (UTM). The study was quantitative, consisting as its population of all 380 postgraduate students. A sample of 191 participants was randomly selected with reference to guidelines from Krejcie and Morgan. Also developed and distributed among the respondents was a questionnaire whose validity and reliability were 0.7 and 0.8 respectively. Findings revealed that Corona-phobia and Movement Control Order developed fear, hopelessness and stigmatization coupled with denial of access to physical library, laboratory facilities, academic consultations, and conducting excursion functions. It is recommended among other things that the UTM authorities should introduce online services, academic activities and programmes to enable E-lectures, E-exams, E-supervision, $E$-submission of thesis, E-proposal defense, $E$-viva presentation, E-approvals, E-corrections, E-visa renewal, and E-visa cancellation etcetera. These will ensure continuity of the educational programmes during the pandemic period and will reduce the boredom, anxiety and depression among students.

Keywords: Corona-phobia, Educational, Impacts, MCO, Psychological, UTM.
\end{abstract}

\section{INTRODUCTION}

A virus known as Covid19 emerged in China at the tail end of 2019, and subsequently became a global pandemic (Wu, Chen \& Chan, 2020). The Covid19 virus is currently a highly infectious virus which spreads rapidly among humans and has been considered responsible for having tremendous health, social and economic impacts on any environment (Aylward \& Liang, 2020). The Covid19 virus is unusual among human respiratory syncytial viruses because of its high infectivity mix, severe lethal consequences, and its potential to cause tremendous social and economic

* Correspondence Author

Sa'adu Isa Bashar*, Educational Foundations, Sokoto State University, Sokoto, Nigeria. Mmbashar1984@gmail.com.

Ramatu M. Maiwada, Educational Foundations, Sokoto State University, Sokoto, Nigeria. ramatumaiwada@gmail.com

Abdulmumini Inda, Department of Arts Education, Faculty of Education Taraba State. Nigeria. abuiitizaz@gmail.com

(c) The Authors. Published by Blue Eyes Intelligence Engineering and Sciences Publication (BEIESP). This is an open access article under the CC BY-NC-ND license (http://creativecommons.org/licenses/by-nc-nd/4.0/)
Revised Manuscript Received on June 13, 2020.

destruction (Aylward \& Liang, 2020). The global communities have been implementing various approaches and initiatives to curb the spread of the virus in their respective locations. Some of the most common interventions implemented by countries include the full or partial lockdown of cities, the prohibition of meetings, social distancing, the closure of educational and religious institutions and many others [1], [2]. With the outbreak of the virus in Malaysia and its substantial increase, the Malaysian government announced on 16 March 2020 a Restriction of Movement Order, also known as the Movement Control Order (MCO), which prohibited mass gathering of people, shut down the premises of religious institutions, company premises - both governmental and private, shut down schools and imposed travel bans or restrictions across the country [3]. To date, the order has passed through its first, second and third phase and was declared effective throughout the country [3]. The fear of being afflicted by the covid19 virus (Corona-phobia) has consumed many people across the globe and has created a series of fears, confusions and suspicions among all of humanity to the point that many people who had not even been diagnosed with the virus cost their lives [2]. For example, [4] reported some social media showcasing an Indian who committed suicide as a result of infection phobia [4]. After lockdowns and travel bans have been implemented in many countries, foreign students from higher education institutions become highly skeptical and flabbergasted in their respective institutes [4]-[6]. Students are faced with reasonable worries about the infection, their safety and family back home [7]. According to [7], the implementation and extension of the Movement Control Order (MCO), students in Universiti Malaysia Pahang might had been stripped of their daily habits and forced to avoid social interactions [7]. Interestingly, Nigerian postgraduate students in the UTM were among thousands of foreign students in Malaysia restrained by the Restriction of Movement Order in the country and could have been influenced by the current trends of the pandemic. However, no empirical study investigating the psychological and educational effects of corona-phobia and the MCO on Nigerian postgraduate students in the Universiti Teknologi Malaysia has been carried out. That is why this study aims to bridge the gap.

\section{OBJECTIVES OF THE STUDY}

The study sought to achieve the following objectives:

i. To determine educational impact of the MCO on the Nigerian postgraduate students in the UTM.

ii. To determine psychological impacts of corona-phobia on the Nigerian postgraduate students in the UTM.

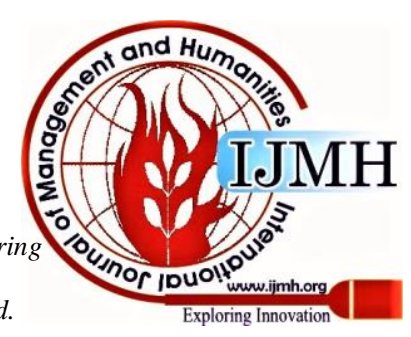




\section{Educational and Psychological Impacts of Corona-phobia and Movement Control Order}

\section{RESEARCH QUESTIONS}

This study attempted to answer the following research questions:

i. What are the educational effects of MCO on the Nigerian postgraduate students in the UTM?

ii. What are the psychological effects of corona-phobia on the Nigerian postgraduate students in UTM?

\section{LITERATURE REVIEW}

Some previous studies [8]-[11] carried out in some places around the world had indicated that psychological trauma affects human mental and physical health which finally affects all angles of human endeavors. For instance, [9] disclosed that certain psychological manifestations in people such as anxiety, depression, hopelessness and others are due to some frightening situations or negative experiences perceived by people when they become helpless with regards to their future. In a study conducted by [8] in Turkey which investigated the Mental health, suicidality and hopelessness among university students, it was established that negative mental situations affect greatly the students' academic achievements as they also affect the overall physical and mental health of students. Moreover, a study conducted by [11] which investigated the level of students' self-control in the Nigerian colleges of education, found that there was a strong correlation between good mental health and students' self-control. The authors also discovered that students with some emotional disturbances had a little or less self-control compared to those without psychological disturbances and therefore recommended the authorities concern to devise possible strategies for reducing the situation and improving the level of students' self-control. Based on this, [12] described psychological trauma as a circumstance that makes one feel depressed and helpless and is often defined by one's personal and emotional perception of incidents. Another study carried out in Australia by [10] on stigma and mental health in higher educational institutions, indicated that social stigma affects both the psychological and mental health of some Australian students who were connected to certain social issues and thus exposed them to so many life challenges including difficulties in pursuing their educational undertakings. Moreover, certain scholars such as [7], [13] positioned that the global shutdown of educational institutions has greatly affected the entire educational processes as it has resulted in significant interruptions of teachings and learning, delayed internal evaluations, and resulted in the cancelation of many public qualification tests or their substitution with inferior alternatives.

\section{METHODOLOGY}

The study was a descriptive survey design and its scope was limited to studying only the Nigerian postgraduate students in the UTM. Population of the study was 380 Nigerian postgraduate students in the UTM covering Masters and $\mathrm{PhD}$ levels. A simple random sampling was used to draw the sample from the population and 191 sample size was selected using the Krejcie and Morgan (1970)[14] sampling guidelines. The researchers distributed an online survey (questionnaire) titled 'Impacts of Corona-phobia and MCO on Nigerian Postgraduate Students' (ICMNPSQ) to collect information from the participants. The instrument was valid and reliable at 0.7 and 0.8 respectively. Descriptive statistic was used in the analysis and data was presented in figures and tables.

\section{FINDINGS}

The result of the study was presented in two sectional folds. The first section presented the background information of the respondents in terms of their study level, year of study and gender. Table 1 shows the background information of the respondents:

Table 1: Background data of the respondent

\begin{tabular}{llcc}
\hline 1. & Level of Study & $\mathrm{N}$ & Percent (\%) \\
\hline & PhD & 132 & 72.9 \\
\hline & Master & 49 & 27.1 \\
\hline 2. & Year of Study & $\mathrm{N}$ & Percent (\%) \\
\hline & First year & 40 & 22.1 \\
\hline & Second Year & 83 & 45.9 \\
\hline & Third Year + & 58 & 32 \\
\hline 3. & Gender & $\mathrm{N}$ & Percent (\%) \\
\hline & Male & 157 & 86.7 \\
\hline & Female & 24 & 13.3 \\
\hline
\end{tabular}

Table 1 indicated that the level of study of the respondents of the study was $\mathrm{PhD}$ and Masters students in UTM. The table showed that $132 \mathrm{PhD}$ students made up the $72.90 \%$ of the participants while 49 Masters students constituted $27.10 \%$. This implied that all the Nigerian postgraduate students in UTM were involved in the study. Therefore, there was no level bias in the research. The table also indicated that respondents used in this study differed according to their years of studies. 40 participants $(22.10 \%)$ were in the first year, 83 participants (45.90\%) were in the second year, while 58 respondents (32\%) were in the third year and above. This suggested that all the Nigerian postgraduate students in UTM irrespective of their years of study were involved in the study. Moreover, the table indicated that the participants in the study comprised of both males and females. Therefore, the study lacks gender bias. The second part of the analysis was made based on the data generated from the respondents to answer the research questions of the study. In the analyses, any mean score that is less than or equals to $2\left(\sum \leq 2\right)$, was considered as "disagreed" opinion of the respondents, any mean score that equals to $3\left(\sum=3\right)$, was considered as a "neutral" ground of the respondents, while, any mean score that is equal or greater than $3.5\left(\sum \geq 3.5\right)$, was considered as an "agreed" opinion of the respondents. All the responses were presented in tables.

Research question 1: what are the educational effects of MCO on the Nigerian postgraduate students in the UTM? Responses on this research question had been generated from the respondents and were presented in table 2:

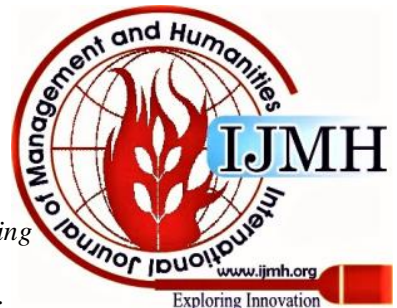


Table 2: Educational impacts of MCO on students

\begin{tabular}{|l|c|c|r|}
\hline \multicolumn{1}{|c|}{ Statements } & $\mathrm{N}$ & Mean & $\begin{array}{c}\text { Std. } \\
\text { Deviation }\end{array}$ \\
\hline $\begin{array}{l}\text { It restricts access to physical } \\
\text { library services }\end{array}$ & 181 & 4.2431 & 1.16739 \\
\hline $\begin{array}{l}\text { It restricts access to } \\
\text { laboratory services }\end{array}$ & 181 & 4.3591 & 1.15868 \\
\hline $\begin{array}{l}\text { It restricts access to study } \\
\text { room }\end{array}$ & 181 & 3.6961 & 1.58515 \\
\hline $\begin{array}{l}\text { It restricts face-to-face } \\
\text { contact with supervisor }\end{array}$ & 181 & 4.6575 & .65304 \\
\hline $\begin{array}{l}\text { It restricts access to } \\
\text { fieldworks/ excursion } \\
\text { functions }\end{array}$ & 181 & 4.5249 & .97507 \\
\hline $\begin{array}{l}\text { It restricts from attending } \\
\text { workshops }\end{array}$ & 181 & 4.4807 & 1.11849 \\
\hline $\begin{array}{l}\text { It restricts from attending } \\
\text { academic conferences }\end{array}$ & 181 & 4.6354 & .96013 \\
\hline $\begin{array}{l}\text { It restricts academic } \\
\text { consultations }\end{array}$ & 181 & 4.6906 & .85853 \\
\hline $\begin{array}{l}\text { It restricts from making new } \\
\text { academic connections }\end{array}$ & 181 & 3.8729 & 1.46833 \\
\hline
\end{tabular}

Data presented in table 2 indicated that majority of the participants agreed that the Movement Control Order rule has effects on students' academic attainment as it restricted the students access to physical library services $(M=4.2431)$, access to physical laboratory services ( $M=4.3591)$, access to study room ( $M=3.6961)$, face-to-face interaction with the supervisors ( $M=4.6575)$, access to excursion functions and field works ( $M=4.5249)$, attending workshops $(M=4.4807)$, attending academic conferences (M=4.6354), making academic consultations (M=4.6906), and making new academic connections ( $\mathrm{M}=3.8729)$.

Research question 2: what are the psychological effects of corona-phobia on the Nigerian postgraduate students' in UTM? Participants attempted to answer this research question by responding to the instruments subjected to them and their responses were presented and analyzed in table 3 :

Table 3: Psychological impacts of corona-phobia on students

\begin{tabular}{|c|c|c|c|}
\hline \multicolumn{4}{|l|}{ se } \\
\hline Statements & $\mathrm{N}$ & Mean & $\begin{array}{c}\text { Std. } \\
\text { Deviatio } \\
n\end{array}$ \\
\hline $\begin{array}{l}\text { It develops fear and } \\
\text { hopelessness among students }\end{array}$ & 181 & 4.4475 & 1.02402 \\
\hline $\begin{array}{l}\text { It makes students loose } \\
\text { self-control }\end{array}$ & 181 & 3.8729 & 1.33765 \\
\hline $\begin{array}{l}\text { It develops social stigma among } \\
\text { students }\end{array}$ & 181 & 4.5580 & .62646 \\
\hline $\begin{array}{l}\text { It develops emotional trauma } \\
\text { among students }\end{array}$ & 181 & 4.6243 & .61668 \\
\hline $\begin{array}{l}\text { It discourages students from } \\
\text { study and learning }\end{array}$ & 181 & 4.3094 & 1.12713 \\
\hline $\begin{array}{l}\text { It discourages academic trust } \\
\text { among students }\end{array}$ & 181 & 4.1878 & 1.14894 \\
\hline $\begin{array}{l}\text { It denied students group } \\
\text { discussion }\end{array}$ & 181 & 4.6188 & .87145 \\
\hline
\end{tabular}

Data presented in table 1 indicated that all the responses were positive in that all the average scores of the respondents were equal or greater than 4 . This implies that majority of the respondents agreed that corona phobia develops fear and hopelessness among students ( $\mathrm{M}=4.4475)$, it makes students loose self-control $(\mathrm{M}=3.8729)$, it develops social stigma among students $(\mathrm{M}=4.5580)$, it develops psychological trauma among students $(M=4.6243)$, it discourages students from study and learning $(\mathrm{M}=4.3094)$, it discourages academic trust among students $(\mathrm{M}=4.1878)$, and denies students group discussion ( $\mathrm{M}=4.6188)$.

\section{RESULT AND DISCUSSION}

It was discovered from the findings of the study that corona-phobia and movement control order had some educational and psychological impacts on Nigerian postgraduate students in the UTM as it has developed some fear, hopelessness, loss of self-control, social stigma, emotional trauma, discouraged learning and academic trust as well as group discussion among the students. These findings had confirmed the findings of other previous studies [8]-[11] which took place in some contexts such as Nigeria, India, Turkey, and Australia. The study by [9] for instance, disclosed that certain psychological manifestations in people such as anxiety, depression, hopelessness and the like emanate due to some frightening situations or negative experiences particularly when people become helpless with regards to their future. In their own study, [8] had also established that negative mental situations affect greatly the students' academic achievements because they also affect the overall physical and mental health of students. Moreover, when [11] studied the level of students' self-control in the Nigerian colleges of education, they discovered clearly that there was a strong correlation between good mental health and students' self-control. They also discovered that students with some emotional disturbances had a little or less self-control compared to those without psychological disturbances and therefore recommended the authorities concern to devise possible strategies for reducing the situation and improving the level of students' self-control. This could be why [12] described psychological trauma as a circumstance that makes one feel depressed and helpless and is defined not by one's objective conditions, but by one's personal emotional perception of the incidents. The findings also complimented the discovery of [10] who found that social stigma affects both the psychological and mental health of some Australian students who were connected to certain social issues and thus exposed them to so many life challenges including difficulties in pursuing their educational undertakings. The study further discovered that the MCO had some effects on the educational attainments of Nigerian postgraduate students in UTM. This was clear because most of the participants agreed that the MCO denied them access to physical library and laboratory facilities, access to study room, face-to-face interaction with supervisors, access to excursion functions and field works, attending workshops and academic conferences, making academic consultations, and making new academic connections.

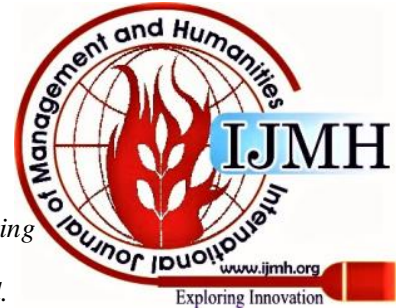


These effects had already been projected by [13] who positioned that the global closure of schools as educational providers has affected the educational processes of schools as it has triggered significant and potential interruptions in learning for students, delayed internal evaluations, and resulted in the cancelation of many public qualification tests or their substitution with inferior alternatives. Furthermore, [7] stressed emphatically that the closure of institutions of higher learning ... coupled with a movement restriction order could make life difficult for students particularly those who are stuck in university premises. The contents of the journal are peer-reviewed and archival. The journal publishes scholarly articles of archival value as well as tutorial expositions and critical reviews of classical subjects and topics of current interest.

\section{CONCLUSION, RECOMMENDATIONS/LIMITATIONS}

The paper concludes by recommending that UTM authorities needs to introduce and implement online activities to enable E-Learning and Examinations, E-supervision, E-submission of thesis, E-proposal defense, E-viva presentations, E-corrections, E-approvals, E-visa renewals and cancellations. The institution needs to fumigate all its campuses and provide sanitizers to all members of the university community. Supervisors need to develop more connections with their students online to help reduce emotional stress for the students. Students need to make a daily schedule of activities to accomplish to avoid redundancy and baseless thought of possibilities. Students need to keep talking to their friends, families, colleagues and supervisors online to avoid boredom and emotional stress. Students need to avoid fake news from the social-media but read from the reliable sources such as ministries of health and other newspapers. However, like all other studies, this research has some possible limitations such as that it was purely quantitative, studied only the Nigerian postgraduate students in the University Teknologi Malaysia and used a survey as instrument for data collection. Since there are other international students in the University, there is a need for replicating the study to other international students other than Nigerians. The study could also be replicated using qualitative or mixed methods. Nonetheless, it is our hope that if the recommendations proffered are acted upon, the impact will be felt by not only Nigerians but all international students in the University. May we see the end of the fight against the pandemic Covid19 as we adhered to "stay safe" historic strategy for containing the likes of corona.

\section{REFERENCES}

1. Y. Niud and F. Xu, "Deciphering the power of isolation in controlling COVID-19 outbreaks," Lancet Glob. Heal., vol. 8, no. 4, pp. e452-e453, 2020.

2. M. Zarghami, "Psychiatric Aspects of Coronavirus (2019-nCoV) Infection," Iran. J. Psychiatry Behav. Sci., vol. 14, no. 1, pp. 2019-2021, 2020.

3. BakerMcKenzie, "Malaysia: Restriction of Movement Order," Insight, 2020.

4. K. Goyal, P. Chauhan, K. Chhikara, P. Gupta, and M. P. Singh, "Fear of COVID 2019: First suicidal case in India!," Asian J. Psychiatr., vol. 49, no. February, p. 101989, 2020.

5. J. Bedford et al., "COVID-19: towards controlling of a pandemic," Lancet, vol. 395, no. 10229, pp. 1015-1018, 2020.
6. Y. C. Wu, C. S. Chen, and Y. J. Chan, "The outbreak of COVID-19: An overview," J. Chinese Med. Assoc., vol. 83, no. 3, pp. 217-220, 2020.

7. M. AbuKarim, "Handling Students' Mental Health during MCO," New Straits Times, pp. 1-2, 15-Apr-2020.

8. D. Gulec Oyekcin, E. M. Sahin, and E. Aldemir, "Mental health, suicidality and hopelessness among university students in Turkey," Asian J. Psychiatr., vol. 29, no. November 2016, pp. 185-189, 2017.

9. V. Hope and M. Henderson, "Medical student depression, anxiety and distress outside North America: a systematic review," Med. Educ., vol. 48, pp. 963-979, 2014.

10. J. M. Martin, "Stigma and student mental health in higher education," High. Educ. Res. Dev., vol. 29, no. 3, pp. 259-274, 2010.

11. E. N. Nwagu, J. C. Enebechi, and A. N. Odo, "Self-Control in Learning for Healthy Living Among Students in a Nigerian College of Education," SAGE Open, vol. 8, no. 3, 2018.

12. L. Robinson, M. A. Melinda Smith, and J. Segal, "Emotional and Psychological Trauma," Help Guide, 2020. [Online]. Available: https://www.helpguide.org/articles/ptsd-trauma/coping-with-emotiona l-and-psychological-trauma.htm. [Accessed: 15-Apr-2020].

13. S. Burgess and H. H. Sievertsen, "Schools, skills, and learning: The impact of COVID-19 on education," University of Bristol, 2020.

14. R. V. Krejcie and D. W. Morgan, "Determining Sample Size for Research Activities," Educ. Psychol. Meas., vol. 30, pp. 607-610. 1970 .

\section{AUTHORS PROFILE}

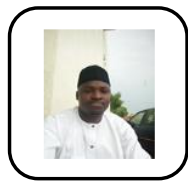

Sa'adu Isa BASHAR, is a lecturer in the unit of Educational Management and Administration, Department of Educational Foundations, Faculty of Education, Sokoto State University, Sokoto, Nigeria. Currently, he pursues his Doctor of Philosophy (PhD) degree in Education (Educational Management and Administration) at the Universiti Teknologi Malaysia. Prior, he obtained a Master's degree in Education (Educational Management and Administration) from the Islamic University in Uganda and Bachelor's degree in Education from the Usmanu Danfodiyo University, Sokoto, Nigeria. He attended and presented papers at different national and international conferences. He published many research articles and chapters in many national and international referred journals, Scopus-index journals, book chapters and conference proceedings. He is a member of the Nigerian Association for Educational Administration and Planning (NAEAP). He is also a member of the Primary and Tertiary Teacher Education Association of Nigeria (PATTEAN).

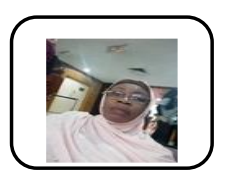

Ramatu Muhammad MAIWADA, is a lecturer with the Department of Educational Foundations, Faculty of Education, Sokoto State University, Sokoto, Nigeria. She is presently a $\mathrm{PhD}$ student in Guidance and Counselling, Universiti Teknologi Malaysia

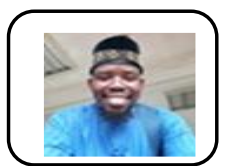

Abdulmumini INDA, is a Lecturer of Islamic Education in the Department of Arts Education, Faculty of Education Taraba State University, Jalingo. Inda had his primary, Grade two, First and Masters Degrees certificates from 1983-2015. He attended Central Primary School Karim, Arabic Teachers College Song, Federal College of Education Yola and Ahmadu Bello University, Zaria Nigeria. Currently he is a PhD candidate in the field of Curriculum and Instructions, University Teknologi Malaysia. He published many scholarly articles in respectable local and international Journals. And he is an active member of Nigeria Association of Teachers of Arabic and Islamic Studies (NATAIS) and he registered with Teachers' Registration Council. He is a team member with a renown international conference organizer (Connecting Asia) He is the CEO International Centre for Islamic Education, Ardo kola, Taraba State. The author love teaching and research. He is happily married with children.

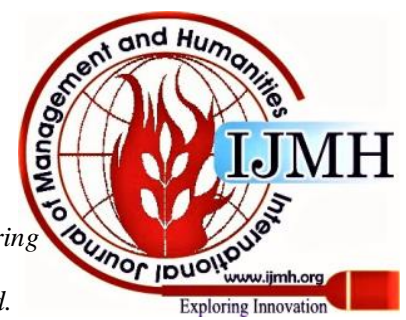

